\title{
Analyses of the Sediment Toxicity of Monjolinho River, São Carlos, São Paulo State, Brazil, using Survey, Growth and Gill Morphology of Two Fish species (Danio rerio and Poecilia reticulata)
}

\author{
Aline Fernanda Campagna ${ }^{1} *$, Renata Fracácio $^{2}$, Beatriz Kawamura Rodrigues $^{3}$, Márcia \\ Noélia Eler ${ }^{3}$, Nelsy Fenerich Verani $^{2}$ and Evaldo Luiz Gaeta Espíndola ${ }^{3}$ \\ ${ }^{I}$ Faculdade de Zootecnia e Engenharia de Alimentos; Campus da USP; Avenida Duque de Caxias Norte, 225; \\ aline.campagna@gmail.com; 13635-900; Pirassununga - SP - Brasil. ${ }^{2}$ Departamento de Hidrobiologia; UFSCar; \\ 13565-905; São Carlos - $S P$ - Brasil. ${ }^{3}$ Departamento de Hidráulica e Saneamento; \\ CRHEA/NEEA/SHS/EESC/USP; C.P. 359; 13566-590; São Carlos - SP - Brasil
}

\begin{abstract}
The objective of this work was to evaluate the toxicity of the sediments of the Monjolinho River (São Carlos - São Paulo/Brazil), through partial chronic toxicity bioassays with juveniles of D. rerio and P. reticulata. Histological analyses of the gills and biometric measurements were conducted to detect the possible deleterious effects that caused the death. In all points the sampled the alterations were found in the gills (hyperplasia, fusion of secondary lamellas and dilation of blood vessels), with the most intense lesions (second stage) occurring at the point two. The biometric analysis pointed to inadequate conditions for the growth of the test-organisms when exposed to the sediment samples. These results showed that the conditions of these environments were not suitable for the survival and growth of these fishes.
\end{abstract}

Key words: Sediment Toxicity, Danio rerio, Monjolinho River, Poecilia reticulata

\section{INTRODUCTION}

Aquatic ecosystems generally reflect all the impacts generated by a series of activities in their hydrographic basin (Tundisi et al., 1999). Pollutants can build up in the sediments, which through natural processes and human interference can be stirred up into the water column by the resuspension, affecting benthic and nektonic organisms (Salomons, 1987; Soares et al., 1999). In this sense, the toxicity tests together with the physical and chemical analyses used to detect and quantify the chemical substances present in the water ecosystems are important tools to assess the toxic potential of sediments on the aquatic organisms. In degraded environments, where pollutants occur more frequently in chronic and sub lethal concentrations, changes in the structure and function of aquatic organisms occur more often than mass die-offs. In this way, the chronic effects detected, in longer exposures, are important to evaluate the effects on the structure of the communities. Some biomarkers are used to interpret the toxicity of aquatic ecosystems, which include the survey, growth and morphology of gills.

\footnotetext{
${ }^{*}$ Author for correspondence
} 
The gills of aquatic organisms are a primary focus of disturbances caused by the action of pollutants, since they are in direct contact with the external environment, carrying out their functions of gas exchange and ion balance. (Poleksic and MitrovicTutundzic, 1994). According to Ewald (1995), the histological damages are preceded by the biochemical and physiological responses, and when detected in the organisms exposed in toxicity bioassays, the adverse effects are unquestionable. Based on this, the objective of the present study was to evaluate the toxicity of the sediments of the Monjolinho River, using partial chronic toxicity bioassays (seven days' exposure) with juveniles of
$D$. rerio (standardized species) and $P$. reticulata (species adapted to the system studied), as well as through the histological analyses of their gills, survey and growth alterations.

\section{MATERIALS AND METHODS}

\section{Study area and sampling sites}

The watershed of the Monjolinho River covers an area of roughly $275 \mathrm{Km}^{2}$, mostly lying within the municipality of São Carlos, in the State of São Paulo, Brazil (Fig. 1).

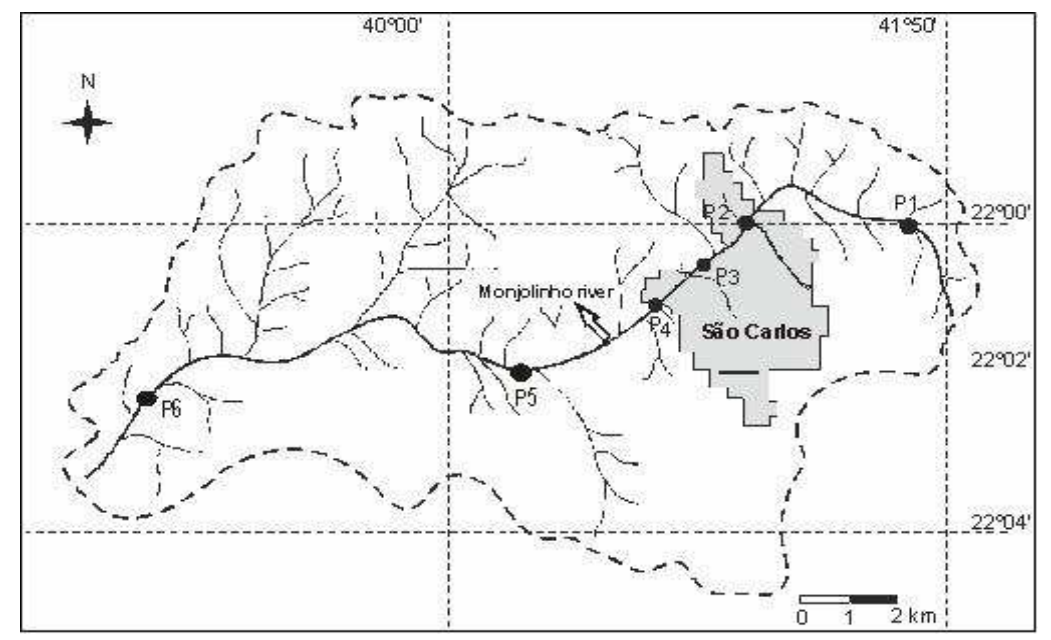

Figure 1 - Map of studied area showing sampling sites. Source: Sé (1992).

This sub-basin is part of the Jacaré-Guaçu River hydrographic basin, which one of the important tributaries on the right banks of the Tietê River (Espíndola, 2000), flowing through the city of São Paulo. It is marked by the urban development of the city of São Carlos, as well as the impacts from the city's activities, such as release of raw domestic and industrial sewage (about 600 establishments) and agricultural runoff. To evaluate the toxicity of the sediments, two collections, one in July 2003 (dry season) and the other in January 2004 (wet season) were conducted at six points along the Monjolinho River (headwaters to mouth), being two them (points two and three) in the urban area and the remaining (points one, four, five and six) in the rural area (Fig. 1).

\section{Sediment sampling and physical and chemical analyses}

The sediment samples were obtained using an Eckman-Birge grab, with three repetitions at each point that were immediately homogenized. A part of the collected material was kept at ambient temperature for the drying and later analysis of the concentration of organic material according to Trindade (1980), grain size as suggested by ABNT (1968) and bioavailable metals according to Silvério (1999). The second portion was preserved at $4^{\circ} \mathrm{C}$ for the toxicity bioassays.

\section{Partial chronic toxicity bioassays}

The juveniles of $D$. rerio and $P$. reticulata were obtained commercially and submitted to sensitivity tests with the potassium dichromate for $96 \mathrm{~h}$, to determine the $\mathrm{LC}_{50}$ and evaluate the health of the test organisms. Then the groups evaluated were used in the sediment samples with the 
methodology described by Burton and MacPerson (1995), which consisted of maintaining a 1:4 proportion of reconstituted sediment to the water, performing three repetitions with 10 specimens each. The aeration was constant, the photoperiod (12:12 dark:light) and temperature $\left(25 \pm 1{ }^{\circ} \mathrm{C}\right)$ were controlled, and every $48 \mathrm{~h}$ the $\mathrm{pH}$, hardness and conductivity of the water and fish mortality were recorded. The bioassays lasted 7 days and the fishes were fed daily.

\section{Evaluation of the toxicity results}

To assess the mortality results and toxicity level of the different sample points, the recommendations of Prater and Anderson (1977) were used with: 030 - low toxicity; 31-50 - medium toxicity; and 51$100 \%$ - high toxicity.

\section{Weight and standard length measurements}

The standard length and weight of the surviving organisms in the tests were evaluated with a high precision scale and gage, respectively. The data were compared statistically to the measures obtained with the control organisms through Mann-Whitney non-parametric test, allowing the detection of chronic effects on the growth and development of the test organisms. This assessment was not done with the bioassays that produced mortality above $90 \%$ due to deficient data.

\section{Histological assessment of the gills}

The histological studies were carried out on the gills of the organisms that survived the partial chronic tests with the sediment samples (in July 2003 and January 2004). After the tests, the specimens were fixed in Bouin's fluid, dehydrated and embedded in the paraffin, sliced into 4.0- to $6.0-\mu \mathrm{m}$ seriated cuts using a MICRON HM 340E microtom and steel blade, stained with Haematoxylin and Eosin (HE), and then studied under an optical microscope. The type and degree of alterations were based on Poleksic and Mitrovic-Tutundzic (1994).

\section{RESULTS AND DISCUSSION}

The granulometric composition of the Monjolinho River sediments differed according to the sample periods and collection point. In general, were found sandy sediment, with predominance of gross, medium and find sand fractions (Table 1). Regarding percentages of organic material, the Monjolinho River sediment was largely inorganic throughout the study (above 10\%) (Table 2). The predominance of inorganic material, combined with the sandy composition of the sediments, could favor the availability of pollutants to the water column, as this was directly related with the capacity to absorb pollutants, i.e., the finer fractions (silt and clay) have a greater surface area for contact in proportion to volume, and thus greater capacity to bind to pollutants (Burton, 2002). Hence, the sediments of the Monjolinho River could represent a toxic potential to the nektonic and planktonic organisms.

The bioavailable metals were present at nearly all the sample points, and most of the concentrations were higher in the dry season, probably because of lower dilution of the pollutants (Table 3). The values were highest in the point two for most of the bioavailable metals. However, the mortality rates of $D$. rerio and $P$. reticulata in the partial chronic toxicity bioassays were in the rainy period (Figure 2). This could have occurred because of the mixture of pollutants, since the metal analyses were conducted separately, not providing explicability in relation to the consequences of these mixtures. Indeed, Espíndola et al. (2003), in computing the correlation between the concentration of bioavailable metals in sediment samples from the Mogi-Guaçu River and the toxicity responses of the organisms tested (Ceridaphnia dubia; Daphnia similis and Chironomus xanthus) found contradictory results, and stressed that in the environmental samples, where there were mixtures of elements, the relation between the concentration and toxic effect was not direct. 
Table 1 - Granulometric composition of sediments from the Monjolinho River (Brazil).

\begin{tabular}{ccccccccccc}
\hline & \multicolumn{10}{c}{ Granulometry (\%) } \\
\hline $\begin{array}{c}\text { Collection } \rightarrow \\
\text { Periods }\end{array}$ & JULY 2003 & \multicolumn{10}{c}{ JANUARY 2004 } \\
$\begin{array}{c}\text { Sampling } \\
\text { sites } \downarrow\end{array}$ & VFG & GS & MS & FS & S+C & VFG & GS & MS & FS & S+C \\
\hline $\mathbf{1}$ & 3 & 22 & 42 & 33 & 0 & 0 & 18 & 50 & 31 & 0 \\
$\mathbf{2}$ & 0 & 22 & 56 & 4 & 17 & 0 & 2 & 51 & 36 & 10 \\
$\mathbf{3}$ & 20 & 33 & 33 & 12 & 0 & 17 & 35 & 39 & 8 & 0 \\
$\mathbf{4}$ & 3 & 46 & 38 & 12 & 1 & 5 & 32 & 46 & 16 & 0 \\
$\mathbf{5}$ & 0 & 2 & 73 & 7 & 17 & 3 & 10 & 37 & 49 & 0 \\
$\mathbf{6}$ & 0 & 1 & 5 & 64 & 30 & 0 & 0 & 35 & 58 & 5 \\
\hline
\end{tabular}

VFG: very fine gravel; GS: gross sand; MS: medium sand; FS: fine sand; $\mathbf{S}+\mathbf{C}$ : silt + clay.

Table 2 - Percentage or organic material at the different sample sites of the Monjolinho River (Brazil).

\begin{tabular}{ccccc}
\hline $\begin{array}{c}\text { Collection } \rightarrow \\
\text { Periods } \\
\text { Sampling sites } \downarrow\end{array}$ & OM (\%) & IM (\%) & OM (\%) & IM (\%) \\
\cline { 2 - 5 } & 0.4 & 99.6 & 0.19 & 99.81 \\
$\mathbf{1}$ & 2.15 & 97.85 & 0.63 & 99.37 \\
$\mathbf{3}$ & 0.31 & 99.69 & 0.18 & 99.82 \\
$\mathbf{4}$ & 5.5 & 94.5 & 0.35 & 99.65 \\
$\mathbf{5}$ & 1.04 & 98.96 & 0.14 & 99.86 \\
$\mathbf{6}$ & 4.95 & 95.05 & 0.61 & 99.39 \\
\hline
\end{tabular}

OM: organic matter; IM: inorganic matter.

Table 3 - Concentration of bioavailable metals at different sample sites of the Monjolinho River (Brazil).

\begin{tabular}{ccccccccccccc}
\hline $\begin{array}{c}\text { Metals } \\
(\mathbf{m g} / \mathbf{K g}) \rightarrow\end{array}$ & $\begin{array}{c}\text { Chrome } \\
(\mathbf{C r})\end{array}$ & $\begin{array}{c}\text { Copper } \\
(\mathbf{C u})\end{array}$ & $\begin{array}{c}\text { Cadmium } \\
(\mathbf{C d})\end{array}$ & $\begin{array}{c}\text { Iron } \\
(\mathbf{F e})\end{array}$ & $\begin{array}{c}\text { Manganese } \\
(\mathbf{M n})\end{array}$ & $\begin{array}{c}\text { Zinc } \\
(\mathbf{Z n})\end{array}$ \\
\hline $\begin{array}{c}\text { Collection } \\
\text { periods } \rightarrow \\
\text { Sites } \downarrow\end{array}$ & Jul & Jan & Jul & Jan & Jul & Jan & Jul & Jan & Jul & Jan & Jul & Jan \\
\hline $\mathbf{1}$ & 0.08 & 0.06 & 0.39 & 0.39 & 0.01 & 0.03 & nd & nd & nd & nd & nd & nd \\
$\mathbf{2}$ & 4.00 & 2.31 & 9.51 & 10.39 & 0.04 & nd & 3595 & 8560 & 368 & 86 & 136 & 195 \\
$\mathbf{3}$ & 0.05 & 0.34 & 0.50 & 1.60 & nd & nd & 786 & 7593 & 75 & 80 & 35 & 62 \\
$\mathbf{4}$ & 0.43 & 0.13 & 10.60 & 6.75 & 0.04 & nd & 1979 & 6299 & 240 & 229 & 69 & 116 \\
$\mathbf{5}$ & 0.55 & 0.053 & 7.04 & 1.29 & 0.03 & nd & 778 & 2612 & 206 & 67 & 98 & 37 \\
$\mathbf{6}$ & 1.71 & 0.858 & 13.50 & 8.46 & 0.05 & nd & 0 & 0 & 4 & 610 & 1 & 185 \\
\hline
\end{tabular}

nd - not detected; Jul: July 2003; Jan: January 2004.

Besides this, in the present work, were not considered other types of substances that could be present in the sediment samples. In both the sample periods, $P$. reticulata was more sensitive than $D$. rerio, because at the points sampled; the former had higher mortality rates (Figure 2). This was expected, since sediments, mainly those at polluted spots, have a range of dissolved toxic compounds, some of which could be harmful to one species of fishes, while others are harmful to different species. Anyway, it was possible to observe a relatively high mortality percentage in the bioassays with the sediment samples along the system. Chronic alterations regarding the development of the surviving organisms could be observed since significant differences for their weight and length were found, when compared to the same parameters assessed for the control 
individuals in some of the sediments. The chronic effects on the growth were just observed in the $P$. reticulata in dry season (July 2003) demonstrating again to be a more sensitive species also for this endpoint (Table 4).

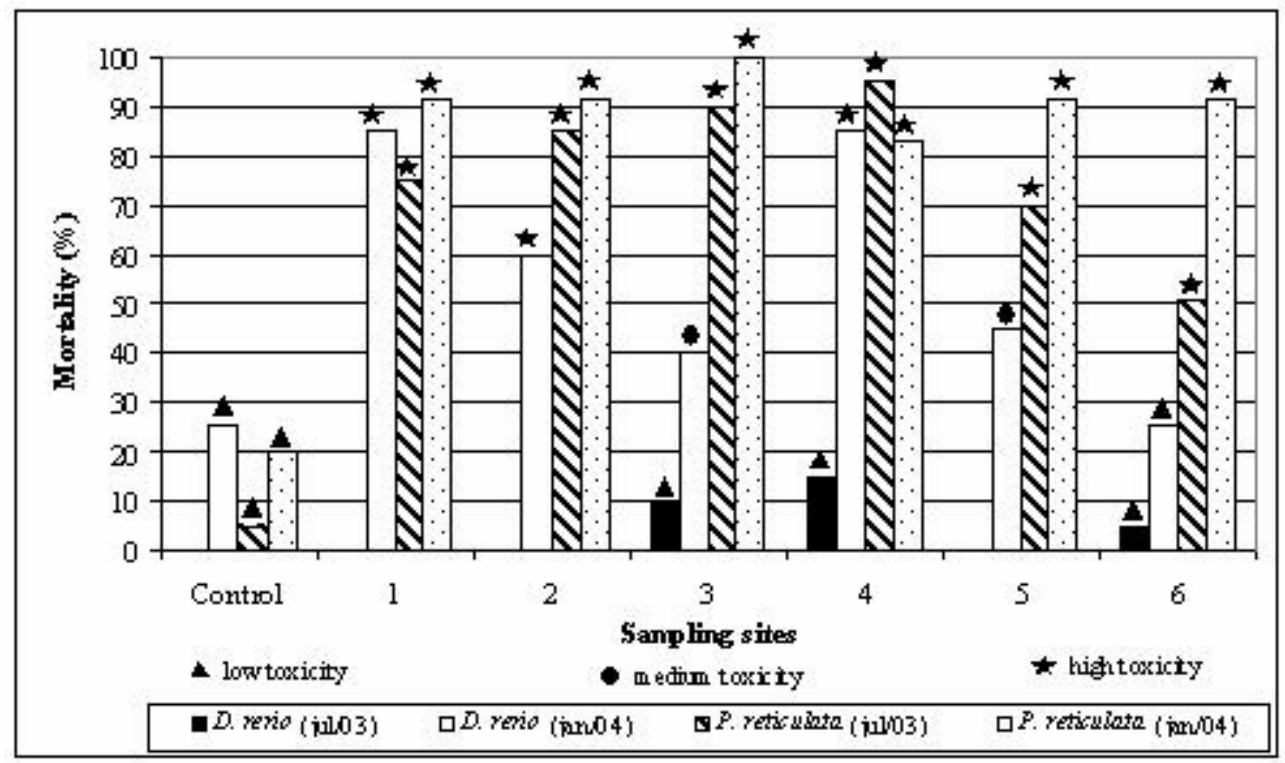

Figure 2 - Mortality percentages of $D$. rerio and $P$. reticulata exposed to sediment samples from the Monjolinho River (Brazil), in the dry season (July 2003) and wet season (January 2004).

Table 4 - Alterations on growth (weight and length) of the organisms of the species $P$. reticulata as compared to measures obtained from control organisms by means of Mann-Whitney test.

\begin{tabular}{ccccc}
$\begin{array}{c}\text { Collection } \\
\text { periods } \rightarrow\end{array}$ & \multicolumn{2}{c}{ July 2003 } & & January 2004 \\
\hline $\begin{array}{c}\text { Parameter } \\
\rightarrow\end{array}$ & $\begin{array}{c}\text { Standard } \\
\text { length } \\
\text { (cm) }\end{array}$ & $\begin{array}{c}\text { Total } \\
\text { weight } \\
(\mathbf{g})\end{array}$ & $\begin{array}{c}\text { Standard } \\
\text { length } \\
(\mathbf{c m})\end{array}$ & $\begin{array}{c}\text { Total weight } \\
\text { (g) }\end{array}$ \\
\cline { 2 - 5 } sites $\downarrow$ & $\mathbf{p}$ & $\mathbf{p}$ & $\mathbf{p}$ & $\mathbf{p}$ \\
\hline $\mathbf{1}$ & $>0,05$ & $>0,05$ & $*$ & $*$ \\
$\mathbf{2}$ & $<0,05$ & $<0,05$ & $*$ & $*$ \\
$\mathbf{3}$ & $>0,05$ & $>0,05$ & $*$ & $*$ \\
$\mathbf{4}$ & $>0,05$ & $>0,05$ & $*$ & $*$ \\
$\mathbf{5}$ & $<0,001$ & $<0,01$ & $*$ & $*$ \\
$\mathbf{6}$ & $<0,01$ & $<0,05$ & $*$ & \\
\hline
\end{tabular}

* Mortality above $90 \%$.

The histological evaluation of the gills was conducted only on the $D$. rerio specimens, because $P$. reticulata showed high mortality in both the sample periods, demonstrating the high toxicity of this compartment for the species in question. The gill tissues of the organisms exposed in the control were normally developed, and it was possible to distinguish the interlamellar spaces (Figure 3A). The gills of the $D$. rerio exposed in the sediment samples in general shows changes, such as hyperplasia of epithelial cells and partial and total fusion of various lamellas, dilation of blood capillaries in the secondary lamellas and central venous sinus, congestion in he secondary lamellas 
and displacement of the epithelium of the secondary lamellas (Figures 3B, C, D, E, F). Among the points along the river sampled, point two showed the highest impacts on the gills of the test organisms, as these was total fusion of all the secondary lamellas, which was a second-stage (Poleksic and Mitrovic-Tutundzic, 1994). Pawert et al. (1998) developed a classification system that related the degree of the alteration in the gill tissues according to the level of pollution of an aquatic system, where they consider that total fusion of two secondary lamellas could be considered exposure to a highly polluted environment. Because of the metal concentrations detected in the sediments, it could be supposed that the lesions identified in the test organisms might be the result of the presence of such substances. At the point two, for example, the metals concentrations were higher, which could have caused the more severe lesions (Figure 3C). Cerqueira and Fernandes (2002), evaluating the recovery of the gill tissues of the individuals of the species Prochilodus scrofa exposed to concentrations of $29 \mu \mathrm{g} / \mathrm{L}$ of copper for $96 \mathrm{~h}$, observed the hypertrophy of the epithelial cells, hyperplasia of the epithelium of the filament, elevation of the branchial epithelium, aneurysms, rupture and hemorrhaging of blood vessels, fusion of secondary lamellas and necrotic cells. According to Sorensen (1991), the Fundunculus heteroclitus exposed to $50 \mathrm{ppm}$ of cadmium for 48 $\mathrm{h}$ presented changes such as hyperplasia, hypertrophy and hipersecretion (increased number of mucous cells). Inflammatory changes, such as swelling, displacement of the epithelium and hyperplasia of lamellas, have often been found in the gills of various species exposed to organic compounds (Roy and Munshi, 1991; Nowark, 1992; Bhavan and Geraldine, 2000; Fanta et al., 2003). According to Mallatt (1985), these changes may reflect a physiological adaptation to stress. Nevertheless, despite protecting the gill areas to ensure the maintenance of the osmoregulatory functions, these can lead to dysfunction or non- functioning of the gills and cause asphyxia (Tamse et al. 1995). The lesions in the gills of the exposed organisms in the samples of January 2004 sediment were more severe, confirming the results of the bioassays of partial chronic toxicity. In this period, the interation between the supposed pollutant in the sediment and the conditions of the aquatic environment turned them more toxic. Fracácio et al. (2003) also that the growth and the gills morphology of the organisms was satisfactory parameters to demonstrate the toxicity of the samples of the sediment from the six cascade reservoirs in the Tietê system in São Paulo State, Brazil, appearing besides sampling points with more severe conditions of contamination. The classification proposed by Polëksic and MitrovicTutundzic (1994) for the gill changes covers three stages of injury, with the third stage being the most serious. According to these authors, the lesions in the first stage can be reverted if the environment improves. If not, these can progress and reach the second stage. In this case, the alterations are more severe and will not likely revert. In the case of chronic exposure, the lesions reach the third stage, in which gill recovery is practically impossible because of the compromising of vital functions, probably leading to the death. Therefore, considering the gill injuries of the organisms exposed to sediments of the Monjolinho River, it was possible to state that the conditions of this environment were not satisfactory for the development and survival of the fishes, and the lesions could become more serious as the system's conditions deteriorated. The degradation of this environment possibly was due to the impacts of the industrial and domestic sewages, of the inadequate use of pesticides and of the modification of the landscape in the basin. These impacts resulted in the chronic effects in the survival, growth and in the morphology of the gills of the fishes, and $P$. reticulata presented larger sensibility in the first two measured endpoints. 

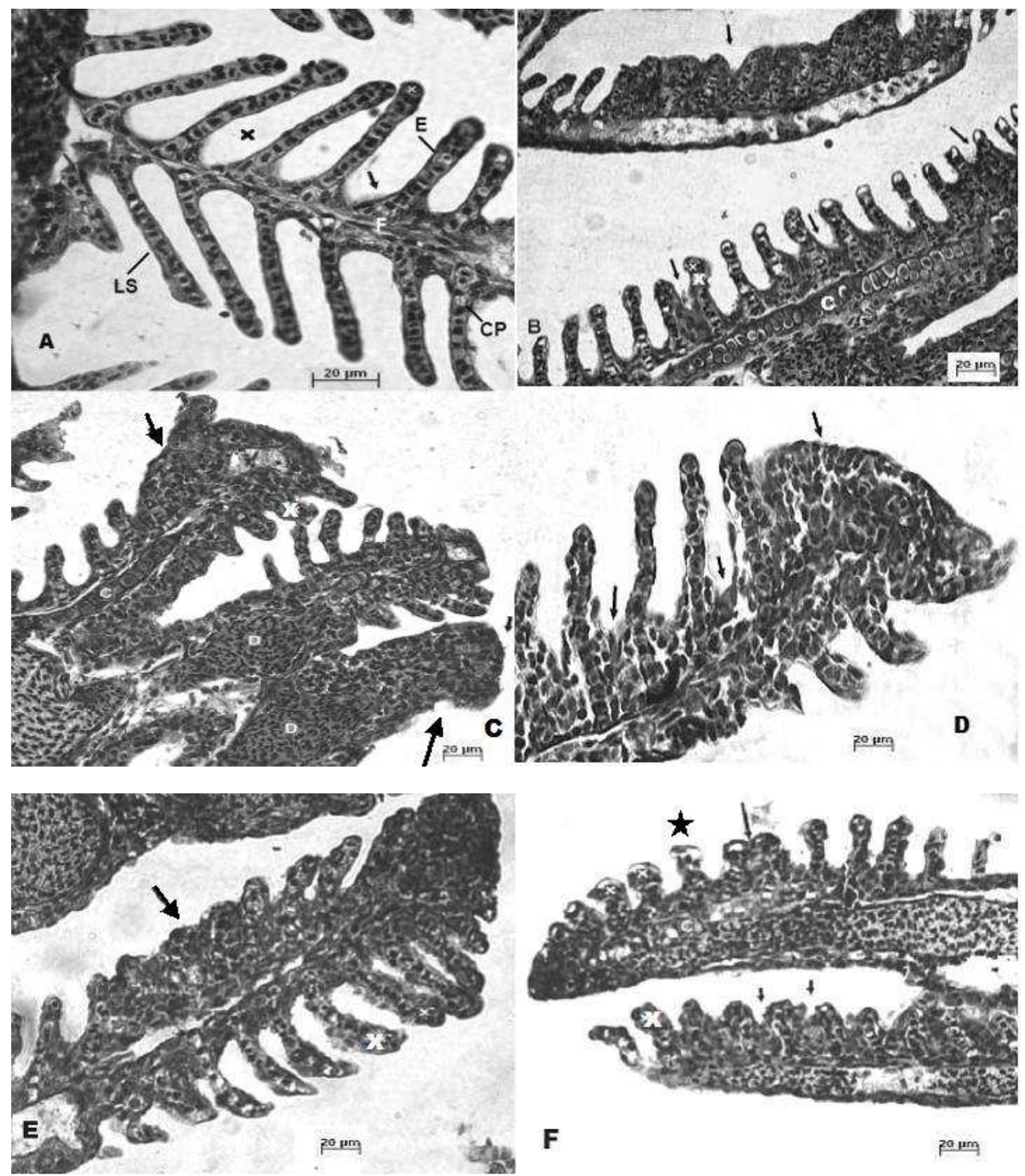

Figure 3 - Histological gill changes of D. rerio exposed to sediments from the Monjolinho River (sagital sections, HE). A. Control organisms. Normal development of the secondary lamellas (LS); branchial filament $(\mathbf{F})$; pillar cells $(\mathbf{C P})$; erithrocytes $(\mathbf{E})$; interlamellar spaces $(\mathbf{X})$ and stratified epithelium of the filament $(\rightarrow)$. B. Organisms exposed at the headwaters (point one); C. Organisms exposed at point two; D. Organisms exposed at the mouth (point six); E. Organisms exposed at the point five; F. Organisms exposed at the point three. Note hyperplasia and fusion of some lamellas $(\rightarrow)$; dilation of capillaries in the secondary lamellas $(\mathbf{X})$; dilation of the central venous sinus (D); lifting of the epithelium in the secondary lamellas ( $\star$ ). Details: cartilage (C). Bar: $20 \mu \mathrm{m}$. 


\section{ACKNOWLEDGEMENTS}

This work was supported by the grants from the Brazilian financing institution (Fundação de Amparo à Pesquisa do Estado de São Paulo FAPESP). The authors thank the Programa de PósGraduação em Zootecnia- Faculdade de Zootecnia e Engenharia de Alimentos/Universidade de São Paulo (PPG-FZEA/USP) and laboratory of Dynamics of Fishers Populations (DHB/UFSCar), as well as the CRHEA/NEEA/SHS/EESC/USP.

\section{RESUMO}

Este trabalho teve como objetivo avaliar a toxicidade dos sedimentos do rio Monjolinho (São Carlos - São Paulo/Brasil), por meio de bioensaios de toxicidade crônicos parciais com juvenis de $D$. rerio e $P$. reticulata. Foram realizadas análises histológicas das brânquias dos organismos para detectar possíveis efeitos deletérios que antecedam a mortalidade. Em todos os pontos amostrados, foram verificadas alterações nas brânquias (hiperplasia, fusão de lamelas secundárias e dilatação de vasos sanguíneos), sendo no ponto dois foram encontradas lesões mais acentuadas (segundo estágio). A análise biométrica dos indivíduos expostos em amostras de sedimento demonstrou condições inadequadas para o crescimento e desenvolvimentos dos organismosteste em todo o ambiente estudado. Os sedimentos apresentaram maior toxicidade no período chuvoso, sendo estes resultados confirmados por meio das análises histológicas das brânquias dos organismos expostos, as quais demonstraram lesões mais acentuadas no mesmo período. Tal situação possivelmente decorre dos impactos antrópicos os quais o sistema está suscetível (efluentes domésticos, industriais e agrícolas), que foram constatados pelas análises físicas e químicas dos sedimentos.

\section{REFERENCES}

Associação Brasileira de Normas Técnicas - ABNT [Brazilian Association of Technical Standards] (1968). Análise granulométrica de solos. 32 p.
Bhavan, P.S., Geraldine, P. (2000), Histopathology of the hepatopancreas and gills of the prawn Macrobrachium malcolmsonii exposed to endosulfan. Aquat. Toxicol., 50, 331-339.

Burton Jr., G.A. (2002), Sediment quality criteria in use around the world. Limnol., 3, 65-75.

Burton, G.L., MacPerson, C. (1995), Sediment toxicity testing issue and methods. In: Hoffman, D.J. Handbook of ecotoxicology. Boca Raton, Lewis Publishers, pp. 70-103.

Cerqueira, C.C.C., Fernandes, M.N. (2002), Gill tissue recovery copper exposure and blood parameter responses in the tropical fish Prochilodus scrofa. Ecotoxicol. Environm. Saf., 52, 83 - 91.

Espíndola, E.L.G. (2000), O Rio Monjolinho: um estudo de caso. In: Espíndola, E.L.G., Silva, J.S.V., Marinelli, C.E., Abdon, M.M. A Bacia Hidrográfica do rio Monjolinho, pp. 36-40.

Espíndola, E.L.G., Brigante, J., Dornfeld, C.B. (2003), Estudos ecotoxicológicos no rio Mogi-Guaçu. In: Brigante, J., Espíndola, E.L.G. Limnologia Fluvial: Um estudo no rio Mogi-Guaçu. pp.129-180.

Ewald, G. (1995), Chronic measures of toxicantinduced effects on fish. Ann Zool. Fenici., 32, 311316.

Fanta, E., Rios, F.S., Romão, S., Vianna, A.C.C., Freiberger, S. (2003), Histopathology of the fish Corydoras paleatus contaminated with sublethal levels of organophosphorus in water and food. Ecotoxicol. .Environ. Saf., 54, 119-130.

Fracácio, R., Verani, N.F., Espíndola, E.L.G., Rocha, O., Rigolin-Sá., Andrade, C.A. (2003). Alterations on growth and gill morphology of Danio rerio (Pisces, Ciprinidae) exposed to the toxic sediments. Brazilian Archives of Biology and Technology, 46 (4), 685695.

Mallatt, J. (1985), Fish gill structural changes induced by toxicants and other irritants: A statistical review. Can. J. Fish. Aquat. Sci., 42, 630 - 648.

Nowark, B. (1992), Histological changes in gills induced by residues of endosulfan. Aquat. Toxicol., 23, 65-83..

Pawert, M; Müller, E; Triebskorn, R. (1998), Ultrastructural changes in fish gills as biomarker to assess small stream pollution. Tissue and Cell., 30 (6), 617-626.

Poleksic V., Mitrovic-Tutundzic, V. (1994), Fish gills as monitor of sublethal and chronic effects of pollution. In: Muller, R., Lloyd, R. Sublethal and Chronic effects of Pollutants on freshwater fish. United Nations, Fishing News Books, pp.339 - 352.

Prater, B.L., Anderson, M.A. (1977), A 96-hour bioassay of Otter Creek. J. Water Pollut. Control Federation, 49, 2090 - 2106. 
Roy, P.K., Munshi, S. (1991), Malathion induced structural and morphometric changes of gills of a freshwater major carp Cirrhinus mrigala (Ham). J. Environ. Biol., 12, 79-87.

Salomons, W., Rooij, N.M. de., Kerdijk, H., Bril, J. (1987), Sediments as a source for contaminants? Hydrobiol., 149, 13-30.

Sé, J.A. S. (1992), O rio Monjolinho e sua bacia hidrográfica como integradores de sistemas ecológicos: um conjunto de informações para o início de um processo de pesquisas ecológicas, de educação e gerenciamento ambientais a longo prazo. Dissertação de Mestrado, Universidade de São Paulo, São Carlos, Brasil.

Silvério, P.F. (1999), Partição, biodisponibilidade e toxicidade de metais pesados a organismos bentônicos em sedimentos. Dissertação de Mestrado, Universidade Federal de São Carlos, São Carlos, Brasil.
Soares, H.M.V.M., Boaventura, R.A.R., Machado, A.A.S.C., Esteves da Silva, J.C.G. (1999), Sediments as monitors of heavy metal contamination in the Ave River Basin (Portugal): Multivariate analysis of data. Environ. Pollut., 105, 311-323.

Sorensen, E.M.B. (1991), Metal poisoning in fish. Boca Raton, Press, 322pp.

Tamse, C.T., Gacutan, R.G., Tamse, A.F. (1995). Changes induced in the gills of Milkfish (Chanos Chanos, Forsskal) fingerlings after acute exposure to Nifuprinol (Furanace; P-7138). Bull. Environ. Contam. Toxicol., 54, 591-596.

Trindade, M. (1980), Nutrientes em sedimentos da represa do Lobo (Brotas - Itirapina). Dissertação de Mestrado, Universidade Federal de São Carlos, São Carlos, Brasil.

Tundisi, J.G.; Matsumura-Tundisi T.; Rocha, O. (1999). Theorical basis for reservoir management. In: Tundisi, J. G., Straskraba, M. Theorical reservoir Ecology and its application. São Carlos, SP. 52 ap.: il.pp.505-528. 